\title{
The Opportunities and Challenges of Jati Plus Perhutani
}

\author{
Corryanti and Novinci Muharyani
}

\begin{abstract}
The teak breeding program has long been conducted by Perum Perhutani and produced superior teak and was named Teak Plus of Perhutani - Jati Plus Perhutani (JPP). With good silviculture practices, JPP-teak of 9 year-old can produce no less than $100 \mathrm{~m}^{3} / \mathrm{ha}$, with $\pm 60 \mathrm{~cm}$ of tree circumstance. The high demand for teak wood is an opportunity to develop JPPteak with fast growing character. Research shows that the quality of JPP wood of 5 and 10 years of age can be classified into Strength Class III. Although the quality of JPP-teak is not equal as the teak gets older, it can be improved through several methods, such as densification, thermal modification, etc. Durability of fast growing JPP-teak can be enhanced by additional treatment with natural or chemical material preservation. Wood color modification can be done through heat treatment method. The color change of JPP-teak of 5 years of age that looked more brownies with variation in value of color change $\left(\Delta \mathrm{E}^{*}\right)$ of 1.04 to 48.53 . Modification technology influenced the properties of teak wood and it is an opportunity of JPP to gain added value as a renewable forest resource product. With teak forest area covering 1.7 million hectares, Perum Perhutani has challenges in developing JPP-teak with more added value.
\end{abstract}

Keywords: JPP-teak, opportunity and challenges

\section{Introduction}

The utilization of teak wood for many purposes mainly because of its natural strength, durability, and beautiful fiber structure. Commercial teak wood usually comes from old teak wood with expensive material and finished product prices. Waiting until teak reaches the maximum age with good quality is assumed as inefficient today. Imbalance of supply and demand can not be avoided. Efforts to produce fast-growing teak is a solution to resolve the issue. However, the nature of this wood needs to be explored further and be compared to the quality of old teak. Perfomance of fast Fast growing performance teak wood coming with low wood quality is a challenge and interesting to be solved to correct the deficiencies.

\section{JPP-Teak}

The teak breeding in Perum Perhutani produces superior clones with fast growing character, known as JPP
(Jati Plus Perhutani). The nine years old JPP-teak may produce timber not less than $100 \mathrm{~m}^{3} / \mathrm{ha}$ with $60 \mathrm{~cm}$ of mean circumference. Intensive silviculture practices (silin) on JPPteak are expected in increasing the performance and productivity. It is mentioned in Basri and Wahyudi (2013) that the application of intensive silviculture can accelerate the heart wood formation and to gain straight stem. For further treatment, touch technology can improve the wood feature.

JPP teak-planting on a large scale was started since 2002 and now have reached not less than 200,000 hectares JPP plantation, spread over the Perum Perhutani forest area in Java. Results of studies on five and ten years old JPP wood (table1) classify JPP-teak into Strength Class-III. The visual observation on five years old JPP teak wood is white coloured dominant since it mostly consists of sapwood and secondary heart wood (Fig. 1-left). On the ten years old JPP teak, the heart wood percentages are between 45.80 $55.95 \%$ varied on different sites.

Tabel 1. Some physical and mechanical feature of JPP-teak of 5 and 10 years old.

\begin{tabular}{llccc}
\hline \multirow{2}{*}{ No } & \multirow{2}{*}{ Parameters } & Unit & \multicolumn{2}{c}{ JPP-wood } \\
\cline { 3 - 4 } & & & 5 years old & 10 years old (d* $^{*}$ \\
\hline 1 & Specific gravity & $\%$ & 0.56 & 0.55 \\
2 & Tangential shrinkage & $\%$ & 4.2 & 3.59 \\
3 & Radial shrinkage & 2.89 & 1.99 \\
4 & MOR & $\mathrm{kg} / \mathrm{cm}^{2}$ & 1001 & 858.37 \\
5 & MOE & $1000 \mathrm{~kg} / \mathrm{cm}^{2}$ & 131.54 & 90.27 \\
6 & Strength class & & $\mathrm{III}$ & $\mathrm{III}$ \\
\hline
\end{tabular}


Source Analyses result from Soil Laboratory, University of Gadjahmada Yogyakarta in Anonymous (2008) and Anonimous (2011).

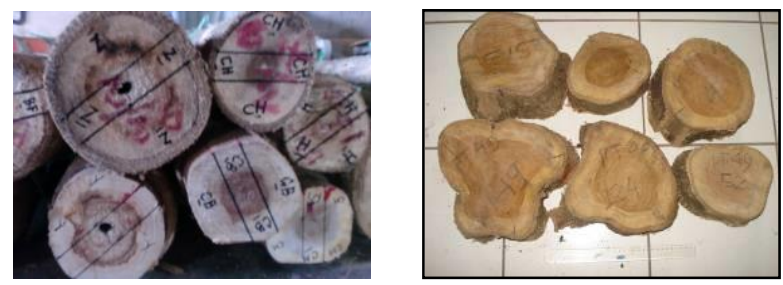

Figure 1. Sampel of JPP teak wood of 5 years (left) and 10 years (right) old.

Efforts to improve the quality of JPP-teak require appropriate technology input to apply environmentally friendly principles to keep the sustainability of the forest (Anonymous 2013). This is in accordance to the sustainability principles adopted by Perum Perhutani in sustainable forest management (SFM). Sustainable forest management will be granted a certificate from the FSC, an independent organization recognized worldwide that supports sustainable forest management. The principles of sustainable forest management are mentioned as follows: (a) No timber harvesting or trading of illegal wood, (b) No violation to the rights of the traditional and human rights in forest management, (c) No damaging high conservation forest value, (d) No forest (natural) conversion to non-forest use, $€$ No entering transgenic species in forest management, and (f) No violation to the ILO conventions (Anonymous 2013).

\section{The Opportunity to Increase JPP-teak Quality and Utilization}

Although many experts suggest cutting age of JPPteak is at above 10 years (Basri and Wahyudi 2013) but in response to market demand, utilization of young wood with a touch of technology can be recommended. Quality improvement can be done through densification or impregnation. Tomme et al. (1998) in Hadiyane (2011) stated the main objective of these approaches are to improve the mechanical properties of the wood such as young's modulus, surface hardness, shear strength, and dimensional stability due to reduced portion of the cavity in wood (porosity) caused by compression. Hadiyane (2011) revealed that process of partial densification on Acacia and Agathis wood can improve physical and mechanical properties of wood, so wood would be more dense and hard, decreasing microfibril angle values and increasing the resistance to termite attack.

The use of heat treatment on five years old JPP using oven, steam, and autoclave at a temperature of 90,120 and $150^{\circ} \mathrm{C}$ for 2 hours was effective to change the color of JPP wood (Muharyani 2012) and the greatest color change was gained by a steam method with total colour change value $\left(\Delta \mathrm{E}^{*}\right)$ of 44.85 (Muharyani et al. 2013) (Fig. 2).

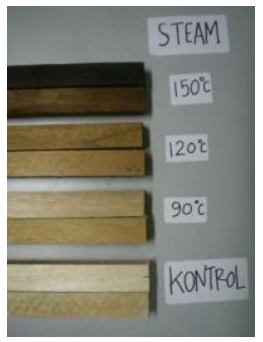

Figure 2. The changing of JPP-teak colour after temperature treatment.

In increasing the utilization of JPP-teak, wood drying needs to be done. Basri and Wahyudi (2013) suggested JPP drying condition as follows: five year-old teak by using temperature of $30-40^{\circ} \mathrm{C}$, seven year-old teak by using temperature of $40-50^{\circ} \mathrm{C}$, and nine year-old teak by using temperature of $40-60^{\circ} \mathrm{C}$. With 2.4 million ha of forest area, Perhutani has a wide-open challenge to increase the value of timber forest product. Differentiation of wood for a variety of different functions is an opportunity to be developed for JPP wood products. Wood as a lignocelulosic materials is a renewable resource and through the process of pyrolysis can be converted into high value products such as charcoal, activated carbon, carbon nano or carbon fiber (Pari 2010).

\section{Conclusion and Recommendation}

JPP-teak is the mainstay of Perhutani for it fast growing character. The opportunity to harvest JPP-teak within a young age with the right technology touch enable to utilize JPP-teak into a new product with a high added value that will give a positive impact on its uses for the people and the planet and also to the benefit of Perhutani as a company.

\section{References}


Anonymous. 2008. Analisis Kualita Kayu JPP umur 10 Tahun asal Tanaman Uji Keturunan. Puslitbang Perhutani. Cepu. Tidak dipublikasikan.

2011. Kajian Kualita Kayu Jati Plus Perhutani. Laporan Penelitian. Puslitbang Perhutani. Cepu. Tidak dipublikasikan.

2013. Penerapan Standard FSC Controlled Wood. Petunjuk Kerja. Perum Perhutani. Unit III Jawa Barat dan Banten. KPH Tasikmalaya.

Basri, E.; Wahyudi, I. 2013. Wood basic properties of Jati Plus Perhutani from different ages and their relationships to drying properties and qualities. Journal of Forest Products Research 31(2): 93-102.

Hadiyane, A. 2011. Perubahan Sifat-sifat Komponen Penyusunan Kayu, Struktur Sel Kayu dan Sifat-sifat Dasar Kayu Terdensifikasi Secara Parsial. Tesis. Sekolah Pascasarjana. Institut Pertanian Bogor. Bogor.

Muharyani, N. 2012. The Effect Of Temperature and Heat Treatment on Wood Properties of 5 Years Old Perhutani Superior Teak (Jati Plus Perhutani). Thesis. Faculty of Forestry. Universitas Gadjah Mada. Yogyakarta.
Muharyani, N.; Prayitno, T.A; and Widyorini, R. Steam Treated Jati plus Perhutani. Disampaikan pada $2^{\text {nd }}$ INAFOR 2013. Dalam pengajuan pada Journal of Forestry Research.

Pari, G. 2010. Peran dan Masa Depan Arang yang Prospektif untuk Indonesia. Orasi Pengukuhan Profesor Riset Bidang kimia Kayu. Puslitbang Hasil Hutan. Balitbang Kehutanan. Kementerian Kehutanan.

Corryanti and Novinci Muharyani

Research and Development Center of Perum Perhutani JI Wonosari Batokan Tromol Pos 5 Cepu, Central Java, Indonesia

Email : corrysambodo@yahoo.com, novincimuharyani@yahoo.co.id 